London School of Economics \& Political Science WORKING PAPERS IN ECONOMIC HISTORY

TEXTILE FACTORIES, TUBERCULOSIS AND THE QUALITY OF LIFE IN INDUSTRIALIZING JAPAN

Janet Hunter

Number: 4/92

June 1992 

Working Paper No. 4/92

\title{
Textile Factories, Tuberculosis and the Quality of Life in Industrializing Japan
}

\author{
Janet Hunter
}

CCDr. Janet Hunter,

June 1992

Economic History Department,

London School of Economics. 
This paper was prepared for an edited volume, Japanese Women Working, to be published in 1993 by Routledge. An earlier version of the paper was given at a seminar at the Institute of Economic Research, Hitotsubashi University, Tokyo in July 1991. I am grateful to Odaka Kōnosuke, Saitō Osamu and Satō Masahiro for their valuable comments, and to Leslie Hannah, Paul Johnson and Dudley Baines for subsequent advice.

\section{Janet Hunter}

Department of Economic History

London School of Economics

Houghton Street

London WC2A $2 \mathrm{AE}$

United Kingdom

Phone: +44 (0)71955 7071

Fax: $\quad+44(0) 719557730$

Additional copies of this working paper are available at a cost of $£ 2.50$. Cheques should be made payable to 'Department of Economic History, LSE' and sent to the Departmental Secretary at the address above. 
Textile Factories, Tuberculosis and the Quality of Life in Industrializing Japan

A striking feature of the modern outlook on tuberculosis is the public recognition of its social and economic setting. Tuberculosis is no longer solely a disease of medical significance and relegated to the physician and the surgeon. Its social and economic implications are far-reaching... [Researchers] have repeatedly shown tuberculosis to be a source of financial loss to the community in wage-earning power and efficiency, which too frequently brings its victim to poverty and destitution. (Sir Arthur S.MacNalty, Chief Medical Officer, Ministry of Health, 1939, in Hart \& Wright 1939:v) 
The incidence of tuberculosis in most of the industrializing countries of the West showed a progressive decline during the late nineteenth and early twentieth centuries, but mortality particularly among young adults remained worryingly high. Nevertheless, recognition of the existence of an etiological relationship between social and economic conditions and tuberculosis, of the kind contained in the above statement, was slow in coming. Doctors in Western Europe and the United States for long failed to agree on the causes of the spread of tuberculosis, let alone on how to cure it. Only from the 1880 s did the majority of doctors begin to abandon the belief that tuberculosis was caused purely by hereditary or 'moral' factors in favour of regarding it as a communicable disease spread by bacilli (Smith 1989:47). Even after it was recognised that the disease was communicated by more than one variety of bacillus, introduced into the body by the inhalation of infectious droplets or ingestion of foodstuffs, disagreements continued over how best to prevent the spread of infection and cure the afflicted. Debates raged over the relative importance of heredity and environment in individuals' predisposition to the disease. Correlations between poor working and living conditions, general poverty and high tuberculosis contraction and mortality rates began to be substantiated after the turn of the century, but the results of research were often obscured by vested medical and other interests, while their practical implications were costly and difficult to implement. For both these reasons they failed to have a rapid impact on prevention and treatment strategies (Smith 1989:46ff.; Teller 1988). 
In Japan the environmental contribution to the contraction of tuberculosis appears to have been recognised, and exhaustively documented, at a relatively early stage. Doctors in Japan and the West were simultaneously exploring this area of research in the first decade of the twentieth century. While Japanese doctors could not necessarily explain the causality any better than some of their Western counterparts, they kept a close eye on advances in European and American research, while also pursuing their own investigations. Researchers enjoyed substantial support from national and local government bodies, and with facilities for treatment virtually non-existent, did not have to contend with powerful vested interest groups. Practical strategies for prevention and cure did not necessarily follow from the publication of research results. Public health policies were in their infancy, and Japan's developing economy could not provide the resources for a national education programme and improved facilities. Nevertheless the question of health, and of tuberculosis in particular, became the object of considerable debate over the years after 1900.

Over the period 1900-1940 Japanese researchers targeted one group in particular - female textile workers. These workers were mostly young (12-20 years of age) and unmarried. Most were dekasegi (migrant) workers, who worked at silk or cotton mills for short periods of a year or two, residing in mill dormitories during their period of employment. They would then move on to alternative employment, 
or return to their native villages, often to marry. ${ }^{1}$ The rural link remained strong, and contemporaries at least until the 1930 s viewed these women as temporarily seconded members of the rural proletariat, rather than fully-fledged members of an industrial one.

The focus on workers in an industry which played such a key role in Japan's early industrialization process led researchers and others to consider more widely the links between health and industrialization. Detailed and well-publicized knowledge of the working life of these women, and in particular of their health, at an early stage put mortality and disease on the agenda as one index of the quality of life in Japan. Writers from as early as the 1890 s were in effect using health data as a proxy for the quality of life of various population groups during the course of industrialization. It was quickly recognised that the anticipated rising per capita GNP over the long run did not mean that there were not 'losers' in the short and medium term; indeed, it was understood that throughout the early decades of industrialization the human cost of much of the process was bound to be considerable. The health and tuberculosis evidence played a crucial part in promoting the view that female textile workers were some of the most definitive losers of all, and this characterization has persisted ever since.

${ }^{1}$ Contemporaries assumed that almost all returned to their villages after mill employment, there to marry, but research suggests that this was not the case (Tanino 1937; Tsurumi 1990:172-3; Molony 1991:224). 
This paper seeks to explain how the high incidence of illness, especially tuberculosis, among female factory workers became an object of concern, to identify factors in their living and working conditions which may have been conducive to the spread of the disease, and to comment briefly on why the issue assumed both historical and historiographical significance.

\section{Mortality and Tuberculosis in Industrializing Japan}

There are conflicting views over trends in Japanese mortality in the Meiji period (Umemura 1988; Okazaki 1986; Saitō 1989; Nishikawa \& Abe 1990:45-59)², but at least after 1920 the process of industrialization was accompanied by declining death rates. However, the aggregate national figures conceal variations in the death rates of different age and occupational groups, and in different regions. During the early decades of the twentieth century contemporaries observed that while female life expectancy in almost all areas of the country was greater than male life expectancy, in certain age groups female mortality rates were much higher than for males. This was particularly true of cities. In 1925-6 death rates of girls aged 10-14 in big cities were $148 \%$ the rates for boys in the same age group. Ten years later the figure was still $143 \%$. Outside the cities it was only marginally less $-139 \%$ and $134 \%$. This

${ }^{2}$ The relationship between mortality rates and economic growth has been a significant element in debates over the standard of living in Western industrialization (see eg. Wrigley \& Schofield 1981; Fogel 1986). 
disparity existed for all age groups up to 40 (Taeuber 1956:306). During the years up to the late 1930 s, female mortality in the puberty -30 age group exceeded male mortality in the same age group by about $20 \%$. Available data suggest that only a very small part of this excess can be explained by problems arising out of pregnancy and childbirth. ${ }^{3}$

Prewar Japan also experienced a marked shift in the major causes of mortality. Following the breach of what has been called the 'cordon sanitaire' by increasing Western contacts from the 1850 s, there was a wave of epidemics of illnesses such as cholera and measles (Jannetta 1986:206). There was then a relative decline in deaths from complaints which could be curbed by environmental control or by direct medical action,such as diarrhoea and gastro-enteritis, dysentery, pneumonia, bronchitis, cholera, smallpox, typhus and typhoid. Significantly, over the same period registered deaths from tuberculosis increased, and from 1934 to 1950 the disease was the leading single cause of death, accounting for $12-14 \%$ of all deaths (GHQ SCAP n.d.:18-38).

Tuberculosis had long been prevalent in Japan, and the absence of reliable data pertaining to any years prior to the twentieth century make an accurate assessment

${ }^{3}$ Data prior to the first full census in 1920 are very patchy, but this gender disparity in mortality rates for specific age groups existed at least from 1900 (Taeuber 1958:305-6). The levels here were also subject to regional variation, and definitive conclusions were rendered more difficult by the constant process of in- and outmigration. 
of the situation very difficult. What is absolutely clear, though, is that the mortality rate from all forms of tuberculosis in Japan, which stood at 160/100,000 around 1900, a level comparable with that in Western Europe, increased dramatically thereafter, reaching a peak in 1918 of $253 / 100,000$. A comprehensive anti-tuberculosis law in 1919 provided for measures such as disinfection and subsidies for sanatoria, but the fresh air, rest and improved nutrition deemed by doctors to be the best treatment were largely unavailable to the poor, and medication was only patchily effective (Powell \& Anesaki 1990:44). The death rate did decline to $179.5 / 100,000$ in 1932, only to rise to $280 / 100,000$ in the appalling circumstances of 1945-6. After 1950, largely due to more effective drug treatment, the rate fell dramatically, though it remained somewhat higher than in many other industrialized countries.

Moreover, mortality statistics cannot necessarily be regarded as a true indicator of the spread of infection. Many Japanese doctors were insufficiently trained to make accurate assessments of patients, and, in Teller's words, 'the diagnosis of incipient tuberculosis was a challenge even to the best clinician' (Teller 1988:86). Tuberculosis was not a legally notifiable disease, and in an environment where the pattern of infection was ill understood contraction often led to social ostracism. It was frequently concealed if at all possible. To save face doctors were often thought to attribute death from pulmonary tuberculosis (phthisis) in particular to illnesses such as pneumonia and bronchitis. The official figures available may therefore be taken as a substantial underestimate of the real situation. 
Figure 1: Comparative Tuberculosis Death Rates: 1900-1948

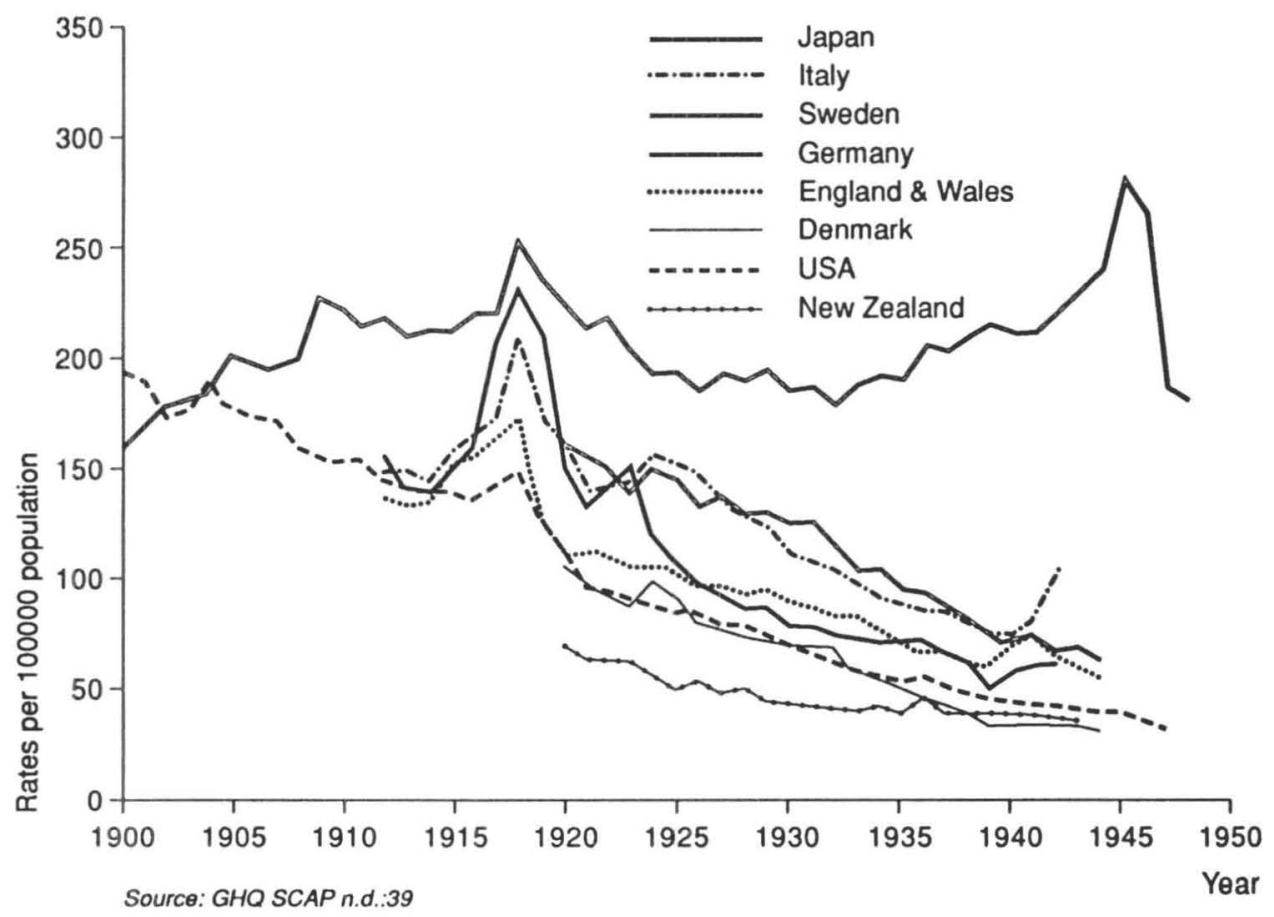


Over the same period in most of the industrialized countries of the West rates of tuberculosis mortality were declining. In Britain, the US and many countries of Western Europe there was a progressive decline from the mid-nineteenth century onwards, well before the introduction of any preventive BCG or other immunization programme or effective chemotherapy. Having recognized a correlation between the incidence of tuberculosis and poverty, authorities in the West noted that this decline in tuberculosis mortality parallelled rising living standards, as measured by conventional indices such as real earnings (Hart \& Wright 1939:20ff.). They disagreed, however, on the cause of the decline.

A significant feature of tuberculosis is that the highest incidence was found among younger age groups (Teller 1988:35; Hart \& Wright 1939:1ff.). Tuberculosis mortality patterns by age show that in early twentieth century Japan this was true for both males and females. It became apparent, however, that more girls contracted tuberculosis at a younger age than did boys. ${ }^{4}$ Medical researchers began to suspect a particularly high incidence of the disease among the young female industrial workers who laboured in the nation's numerous textile mills. In the years after 1900

${ }^{4} \mathrm{~A}$ similar disparity was found in the early twentieth-century in England for girls under twenty-four, but for the older age groups there was a considerable excess of male over female deaths from tuberculosis (Hart \& Wright 1939:12). The peak age for women dying of tuberculosis was 25-35, for men it was older (Smith 1989:17). One suggestion was that this was partly because more women were entering industrial occupations (Hart \& Wright 1939:93). 
research on morbidity and mortality among this group was undertaken, and detailed surveys carried out of days lost through illness in a large number of textile mills.

\section{Research into Factory Health}

The debate over the significance of tuberculosis in Japan must be seen in the context of concern over working conditions and pressure for factory legislation (Kobayashi 1965; Dore 1969; Taira 1970). This pressure developed in Japan from the late 1890s, and was fuelled by the publication of reports such as Yokoyama Gennosuke's Nihon no Kasō Shakai (The Lower Social Strata of Japan) (Yokoyama 1901), and the Agriculture and Commerce Ministry's Shokkō Jijō (Conditions of Workers) (Nōshōmushō 1903). As factory owners showed continuing resistance to state intervention in working conditions, investigators became increasingly concerned about the state of health of workers in the nation's factories. Doctors drew strong and unfavourable contrasts with the Western working environment, castigating Japanese employers for their failure to improve the situation (Yamane 1901:3-5). One writer commented that workers would normally leave bad conditions for better, but because women workers were young and unable to resist the use of force, normal labour market conditions could not operate, so employers had a 'paternalistic' duty towards their employees (Kubota 1902:4). For the most part improvement in worker welfare was argued not for its own sake, but for the sake of national efficiency. Reports frequently mentioned the dire effect on factory productivity of 
the huge numbers of days lost through worker illness (eg. Koinuma 1925:22), and the profits which could accrue from prevention of illness (Kose 1926:214).

Reports on worker health proliferated after 1900, a large number concentrating on the situation relating to female textile workers. A very comprehensive study was carried out 1909-11 by Ishihara Osamu, who was to become particularly famous for his work on tuberculosis (Ishihara 1913a). By the interwar period the government's own statistics clearly showed that the sickness rate for women in all large factories in Japan was much greater than that for men, and was particularly high in textiles (ILO 1933:243) $)^{5}$. Four surveys selected here, two in the cotton industry and two in silk, well represent researchers' findings. One investigator in 1911 conducted a general medical inspection of 1,300 workers in a cotton spinning mill. It appears that health inspection standards on entry were rigorous, and conditions relatively good. While the rate of acute illness was not particularly high, the extent of less acute ailments was immense. No fewer than $42 \%$ (546) were suffering from trachoma (of whom 200 had contracted the disease since entering the factory), and some $13 \%$ had tonsil or throat infections. Large numbers were hospitalized for some period for a range of ailments, including bronchitis and pneumonia. Figures on average height, weight and chest measurements of workers indicated a relatively good state of affairs, but were far below those found in surveys of the admittedly more

\footnotetext{
${ }^{5}$ This report cites the government produced Kōjō Kantoku Nenpō (Factory Inspection Yearbook).
} 
advantaged students in Ministry of Education schools (Ōhashi 1911:22-35). The writer said that the definition of occupational diseases should be extended to include flat-footedness, kerosene-induced nausea and noisy breathing, often a sign of incipient pulmonary tuberculosis.

A later survey carried out in ten Kansai spinning mills in the year to August, 1924 , reported that nearly half the total number of c.12,000 workers in the survey became sick at some point during the period, resulting in an estimated loss of over 50,000 working days. The most common ailments were colds and flu, followed by stomach ailments and beriberi. Tuberculosis figured low on the scale, but still accounted for $43 \%$ of all worker deaths at the mills, and $30 \%$ of all workers discharged owing to sickness. There was a strong seasonal pattern in mill sickness, with illness peaking in January-March, when colds and flu were most common, and again in July-September, when intestinal problems were widespread (Koinuma 1925:21-23).

Patterns in silk mills were similar. An extensive health inspection of over 80,000 Nagano silk workers, the results of which were published in 1924, again showed very high rates of trachoma, respiratory disease and digestive problems. Tuberculosis accounted for a very small number of those inspected, but the survey remarked that it was common knowledge that most workers with suspected tuberculosis were rapidly 
discharged. ${ }^{6}$ Significantly, this survey shows clearly a higher sickness rate for female than male workers (see Table 1).

\begin{tabular}{|c|c|c|c|c|}
\hline & 1920 & 1921 & 1922 & 1923 \\
\hline No. of mills inspected & 413 & 463 & 395 & 354 \\
\hline No. of workers & 80,789 & 74,937 & 85,409 & 81,103 \\
\hline No. sick & 3,605 & 3,615 & 2,774 & 2,240 \\
\hline Sickness rate per 1,000 & 44 & 48 & 32 & 28 \\
\hline No. of women sick & 3,356 & 3,474 & 2,619 & 2,108 \\
\hline No. of men sick & 249 & 141 & 155 & 132 \\
\hline Sick men per 1,000 & 26 & 22 & 15 & 16 \\
\hline Sick women per 1,000 & 49 & 53 & 36 & 19 \\
\hline
\end{tabular}

Source: Rōdō Jihō 1924: 12

The disparity was attributed by the Nagano Factory Inspectorate to the fact that men's work in silk mills was relatively light by comparison with women's, and that most girls' living conditions at the mills were very poor (Rōdō Jihō 1924:11ff.).

A further survey published in 1926 on the basis of sickness notifications issued by silk mills in Nagano drew the same picture of twice yearly peaks, prevalence of colds, flu, respiratory ailments and gastro-intestinal disorders, and, in all, a substantial number of working days lost through illness (Kose 1926:179-195).

\footnotetext{
${ }^{6}$ Even in the 1930s relatively few mills had special facilities for tuberculosis sufferers.
} 
The picture suggested by this data was of a mortality rate higher than average, against a background of recurrent disorders and infections, of both major and minor order. Tuberculosis accounted for a substantial minority of deaths at the mill, but the absolute numbers of such deaths were very small. However, when morbidity and the health of discharged workers were analysed, tuberculosis was found to assume a far greater importance, as will be shown in the next section. Conditions in the textile mills, argued these researchers, were a major contributory factor to the higher than average mortality and morbidity rates among this female age group, and hence the nationwide excess of female over male deaths in these particular age groups.

\section{Tuberculosis}

The spread of tuberculosis was a matter of concern in Japan by the turn of the century. One doctor, writing in 1902, spoke of the spread of pulmonary tuberculosis as a primary area where research was needed, as the available data were totally inadequate. He referred to the fact that it was 'well-known that all forms of tuberculosis, but particularly pulmonary tuberculosis, were spreading in factories using large numbers of women'. This, he said, was likely to be critical for the health and welfare of the nation (Kubota 1902:8). Ten years later Ishihara Osamu, who conducted the most important research work in this area, was able to comment that all factories, but especially big ones, were at their wits end over what to do with the tuberculosis problem (Ishihara 1913b:134). Unfortunately, however, as Taeuber 
poignantly comments, 'families did not analyse the statistics on tuberculosis before they sent a daughter to a textile dormitory' (Taeuber 1956:293).

Ishihara Osamu's writings on the tuberculosis question, known collectively as Jokō to Kekkaku (Mill girls and tuberculosis), resulted from extensive research carried out at the request of the Ministry of Agriculture and Commerce over the years 1909-1911. $\quad$ Ishihara estimated that one out of every 6-7 mill girls returning to the countryside did so with serious illness. $(13,000$ out of 80,000 surveyed in 1910.) Of those workers discharged because of serious illness, around one-quarter $(3,000)$ had tuberculosis.

\begin{tabular}{lrrc}
\hline \hline \multicolumn{4}{c}{ Table 2 Factory Workers Discharged Due to Illness, by Disease (1910) (\%) } \\
\hline & $\begin{array}{c}\text { Cotton } \\
\text { Spinning }\end{array}$ & $\begin{array}{c}\text { Silk } \\
\text { Reeling }\end{array}$ & Weaving \\
\hline Pulmonary Tuberculosis & 26.6 & 3.4 & 20.0 \\
Suspected Pulmonary Tuberculosis & 21.7 & 4.7 & 38.0 \\
Other Tuberculosis & 5.2 & 2.5 & - \\
Beriberi & 1.8 & 4.3 & 11.3 \\
Gastro-enteric illness & 6.7 & 28.4 & 2.0 \\
Other & 38.0 & 56.7 & 28.7 \\
\hline Total & 100.0 & 100.0 & 100.0 \\
\hline \hline
\end{tabular}

Source: $\quad$ Ishihara 1913b: 135

Note: Ishihara also give figures for hemp workers, but the distribution does not total $100 \%$, and these have been omitted.

${ }^{7}$ Ishihara's work is discussed at some length in Kagoyama Takashi's introduction to the 1970 edition of Ishihara's writings (Kagoyama 1970:1-46). Useful comment in English of its findings' importance can be found in Tsurumi 1990:169-172). 
Most came from the cotton spinning industry. Comparing estimated death rates for these factory workers with national mortality rates, Ishihara concluded that the death rates for $16-20$ year old returnees were 14.86 per 1,000 dekasegi (migrant) workers, more than double the national average for the age group. For 20-25 year olds it was 11.67 per 1,000 , around a quarter above the national average (Ishihara 1913b:141). Average mortality rates would imply a figure of 4,000 deaths among this group (female dekasegi workers), whereas the actual rate was 9,000, giving 5,000 'extra' deaths (Ishihara 1913b:142). Of these 9,000 deaths, $70 \%(6,300)$ were caused by tuberculosis, of which over a third $(2,700)$ were due to pulmonary tuberculosis (Ishihara, 1913b: 142)(see Tables 3 \& 4).

Table 3 Factory Worker Mortality by Cause of death, 1906-8 Average (\%)

\begin{tabular}{lrrrr}
\hline & $\begin{array}{c}\text { Cotton } \\
\text { Spinning }\end{array}$ & Silk Reeling & Weaving & $\begin{array}{c}\text { Hemp } \\
\text { Working }\end{array}$ \\
\hline $\begin{array}{l}\text { Pulmonary } \\
\text { Tuberculosis }\end{array}$ & 34.5 & 16.5 & 16.3 & 18.8 \\
$\begin{array}{l}\text { Suspected } \\
\begin{array}{l}\text { Pulmonary } \\
\text { Tuberculosis }\end{array}\end{array}$ & 12.6 & 14.2 & 3.8 & 12.5 \\
$\begin{array}{l}\text { Other Tuberculosis } \\
\text { Beriberi }\end{array}$ & 7.1 & 3.8 & 12.5 & 1.9 \\
$\begin{array}{l}\text { Gastro-enteric } \\
\text { illness }\end{array}$ & 8.2 & 3.8 & 8.8 & 12.5 \\
Other & 4.1 & 10.3 & 8.8 & 6.3 \\
\hline Total & 33.5 & 51.4 & 49.8 & 48.0 \\
\hline \hline
\end{tabular}

Source: Home Ministry figures given in Ishihara 1913b: 144 
Table 4 Returnee deaths by occupation and illness, $1910(\%)$

\begin{tabular}{lrrrcc}
\hline & $\begin{array}{c}\text { Cotton } \\
\text { Spinning }\end{array}$ & $\begin{array}{c}\text { Silk } \\
\text { Reeling }\end{array}$ & Weaving & Other & Total \\
\hline $\begin{array}{l}\text { Pulmonary } \\
\text { Tuberculosis }\end{array}$ & 41.3 & 37.4 & 35.4 & 33.8 & 39.0 \\
$\begin{array}{l}\text { Suspected } \\
\text { Tuberculosis }\end{array}$ & 31.2 & 33.4 & 29.2 & 32.4 & 31.3 \\
$\begin{array}{l}\text { Beriberi } \\
\text { Gastro-enteric }\end{array}$ & 9.9 & 2.4 & 5.0 & 8.8 & 6.4 \\
illness & 6.6 & 11.4 & 11.8 & 4.4 & 8.6 \\
Other & 12.1 & 16.6 & 18.5 & 22.6 & 14.6 \\
\hline Total & $100.0^{*}$ & $100.0^{*}$ & $100.0^{*}$ & $100.0^{*}$ & $100.0^{*}$ \\
\hline \hline
\end{tabular}

Source: Ishihara 1913b: 142-3

*Note: Ishihara's own figures, given here, do not total 100. The reason for this is not explained.

Some prefectures were particularly badly hit. In Yamanashi, for example, 80\% of the returnees who died had tuberculosis, while many other areas reported problems as the disease spread to rural families (Ishihara 1913b:138, 143). Unlike his superior in the Agriculture and Commerce Ministry, Oka Minoru, Ishihara was very explicit on the connection between factory health and the countryside. It was not just in textile dormitories that tuberculosis was becoming one of the most feared diseases, but in the countryside as well.

These mortality figures without doubt understated the true extent of tuberculosis and other illnesses. Ishihara himself noted that the way in which respiratory 
diseases were categorized in the Statistics Office figures he used meant that the tuberculosis rate was probably greater than actually appeared (Ishihara 1913b:144). Moreover, rapid turnover and resignations due to ill health restricted mortality in the factory itself (Ishihara 1913b:138).

The results of Ishihara's research seemed to confirm what many had suspected. Published in stages in subsequent years, the findings were not always popular, and most mills were slow to act upon them. However, many contemporaries considered them to provide incontrovertible proof of the existence of higher tuberculosis morbidity and mortality rates in textile factories than prevailed in the nation as a whole. By implication the results also suggested that the conditions experienced by young female textile workers, especially in cotton spinning, were a contributory cause of those higher morbidity and mortality rates. This conviction seemed to be borne out by later researchers' discovery of similar patterns in other parts of the textile industry. One 1938 report on workers in the Hyōgo silk industry indicated a tuberculosis contraction rate far higher than the prefectural average (Ötsuka 1938:79). Weavers' families seemed particularly prone to the disease (Sanpei 1961:541).

It was in the cotton industry, though, that concern was concentrated, as it was here that Ishihara had assigned the greatest blame. The better mills sought to improve health inspection and working conditions, but tuberculosis remained a serious problem for management throughout the interwar years. The depth of 
concern is revealed in a confidential report drawn up by medical staff at the cotton giant Tōyōbō in 1929, as part of a larger survey mandated by the Home Ministry. The research identified a disproportionately high tuberculosis rate among 1,743 former Tōyōbō workers previously discharged sick. Explaining differential tuberculosis rates between Tōyōbō factories by disparities in skill of diagnosis, the research showed that there was also an immense variation according to the area of recruitment. Looking at the three major areas of Tōyōbō recruitment, it was found that tuberculosis rates in Tōyama and Okinawa were much higher than in Niigata, suggesting that it was not just in the factories that the cause and cure had to be sought. Nevertheless, the existence of a tuberculosis death rate among company workers of 2.5 times the national average, and the fact that the death rate increased with the length of service, could not be ignored. Castigations of the failures of Japanese public health policy could not conceal the distress of the doctor who compiled this report (Tōyōbō 1929:1-28). The concern with tuberculosis among industrial workers demonstrated by official sponsorship of Ishihara's own research continued for most of the interwar years. The government's Social Affairs Bureau took steps to find out the state of research in the West, and pressed for better working conditions. While some bureaucrats were no doubt motivated by humanitarian considerations, an overwhelming concern continued to be national economic efficiency. By the 1920 s it was a matter of concern that Japan's tuberculosis death rate was so much higher than those in countries such as France 
and Germany. Officials sought to publicize their own investigations, which continued to show that young female factory workers were particularly vulnerable to the disease. Graphic illustrations of the kind shown in Figure 2 could hardly fail to have an impact. This figure, of course, depicts the actual recorded number of deaths, and therefore tells us nothing whatsoever about mortality rates (there were still many more women than men in large factories at this time). Nevertheless, the intent of the graph was unambiguous, namely to shock those who viewed it. The authorities pressed for preventive measures, the rejection of vulnerable workers through stringent health inspections, and methods of early detection, which, German research suggested, vastly improved the overall recovery rate. It was openly admitted that tuberculosis was encouraged by poor nutrition and overwork (Shakaikyoku 1926:31$36)$.

Despite efforts of this kind, a later survey on the post-mill experience of female cotton spinning workers, carried out in 1936 by members of the factory inspectorate, continued to show the same kind of story. This survey included both those who left, and those who were discharged, a small sample of 204 in all. Of these, thirty-one had been ill on departure. Fourteen recovered, nine continued sick and eight had died. Of the eight deaths, seven were from tuberculosis. Several of those sick also had tuberculosis. The inspectorate noted that selection standards in the mills covered in the survey were fairly strict; the quality of workers was good, 
Figure 2: Recorded Deaths from Tuberculosis in Textiles and Other Factories, 1917-24

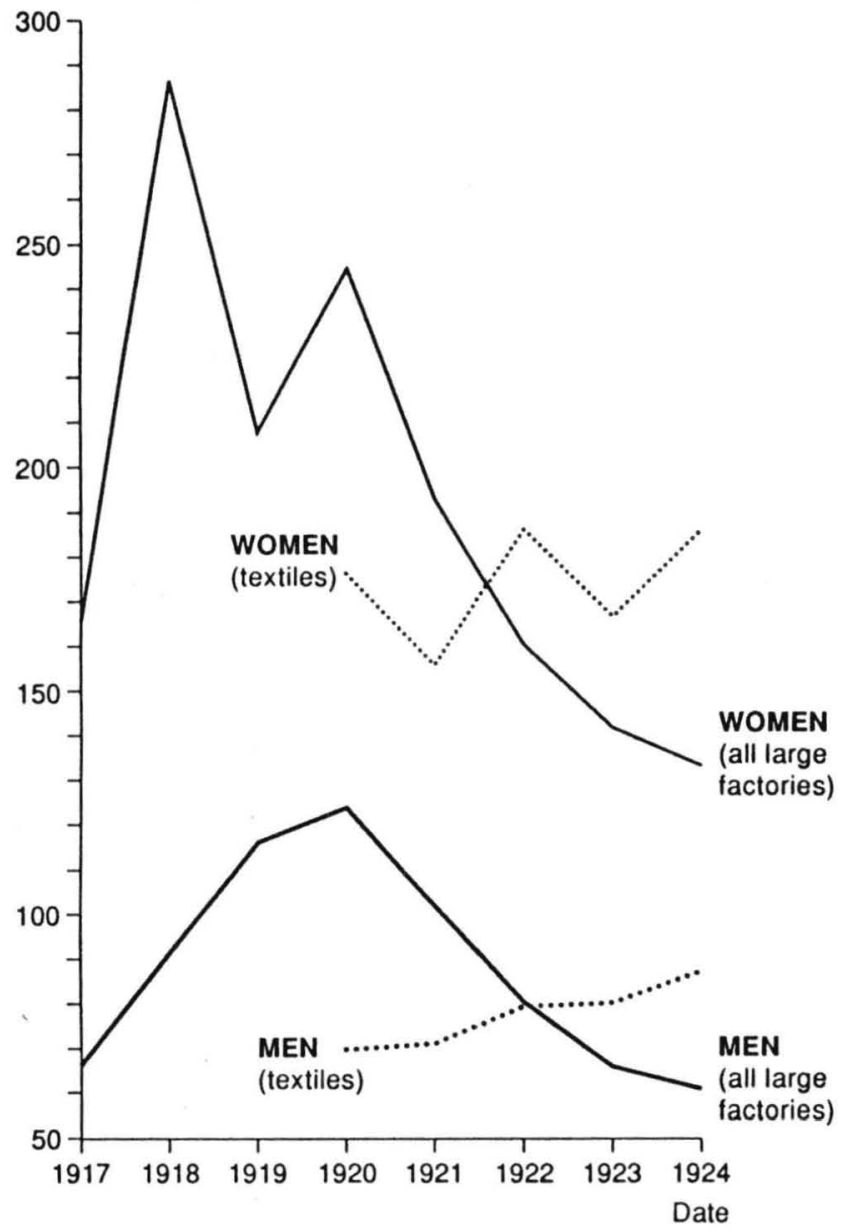

Source: Shakaikyoku 1926: 40 (modified)

Note: Data for all large factories applies to factories with 50 or more workers up to 1921 , amd factories with 500 or more workers from 1922 onwards. Since manv textiles workers (especially weavers) were in small workshops they are thus excluded from the post-1921 industry figures. 
and the mills possessed good medical facilities and managements with a constant eye to tuberculosis. The report expressed concern that tuberculosis patients were being discharged from mills with good medical facilities to families lacking the means to pay for medical care (Tanino 1936:28-30). The writer commented seriously that the prevalence of illness, especially tuberculosis, among these girls indicated the existence of social problems 'which must be taken seriously by intellectuals seeking a better future in which productive work is a joy' (Tanino 1936:32). By 1948 the head of Tōyōbō's welfare section, a medical doctor, was able to make the doubtful claim that the number contracting tuberculosis in cotton mills was lower than the national average (Itō 1948:11), but the national circumstances were distinctly unusual, and national rates also beginning to decline.

\section{The Etiology of Tuberculosis and Japanese Textile Workers' Working and Living}

\section{Conditions}

The relationship between tuberculosis and the standard of life is still inadequately understood, but there is no doubt that living and working conditions can be more or less conducive to the spread of infection. For example, sputum or water droplets containing the bacillus may be allowed to lie around; hence the ordinances relating to spitting in much of Europe and the US. The temperature may be kept at a level which causes the bacilli to be preserved and to multiply $\left(38-41^{\circ} \mathrm{C}\right)$. Conditions which reduced the resistance of the individual to infection could include poor diet and 
exhaustion. As mentioned earlier, however, in the West many doctors and officials were slow to recognise any connection between tuberculosis infection and living and working conditions. Little attention was paid to psychological and emotional factors in tuberculosis contraction, and even after 1900 substantive research in Europe and the US was on a piecemeal basis, though there was a growing interest in the relationship between occupational conditions and the disease. In this context, the wide ranging and systematic investigations carried out by Ishihara in the first decade of the twentieth century were of a path-breaking nature. ${ }^{8}$ In Ishihara's view, and in the view of his successors, the correlation between inferior living and working environment and tuberculosis, especially in the cotton spinning industry, was quite unambiguous. While the implications and costs of accepting these findings were considerable, mill doctors, managers and the state were forced to take note. While some of the causality could be disputed, it proved virtually impossible to explain away or ignore the actual research results.

It is well known that from the 1890 s onwards, contemporaries were describing working conditions which they regarded as unacceptably poor, even by contemporary standards (eg. Yokoyama 1898; Nōshōmushō 1903; Hosoi 1925). Conditions of life among female textile workers appeared to compare unfavourably both with those of male industrial workers, and with the conditions most of these women would have

${ }^{8}$ There is no evidence that Ishihara's findings were ever translated into English, and one can only speculate on the impact had this happened. 
experienced had they remained in the rural sector. Conditions improved over the years up to the 1930s, but in many places remained poor. Even allowing for some exaggeration of the horrors of new and unfamiliar conditions, or for anti-urban bias, there is plenty of evidence that on a variety of counts identified by medical opinion as conducive to the spread of tuberculosis, conditions in the mills provided ideal breeding ground for the illness. There are several environmental factors which historically show a strong correlation with the spread of tuberculosis (particularly pulmonary tuberculosis), and which are now recognised by doctors to be of significance. The next section will seek to identify how far these factors may have been relevant in the case of Japanese textile workers. It is not my intention here to assign an exact causality for high rates of tuberculosis among mill workers, since it is is not possible to determine which factor was most significant. It is important to note that both in Japan and elsewhere these factors have invariably gone hand in hand, and together act as an important determinant of higher rates of tuberculosis among the less well-off. It is apparent from any such analysis of environmental tuberculosis causality, textile workers do pretty badly. The total package of living and working conditions experienced by these workers would make them 'score', to whichever of the various factors was attributed the most importance. 


\section{Working Environment}

Both in Japan and in the West some occupations had much higher tuberculosis rates than others. In Britain metal workers, tailors, shoemakers, bakers, seamstresses, masons and printers appeared particularly vulnerable (Smith 1989:212). In Japan, apart from textiles, rubber workers experienced high rates of tuberculosis; rates increased with length of service in the industry, giving a different profile from national tuberculosis contraction rates (Ōtsuka 1938:77-78). The disease seemed most prevalent in small workshops, and in dirty and ill-ventilated workrooms. Significantly, it was suggested in the 1890 s that female cotton operatives in the UK were comparatively healthy, because they were not in huddled workrooms (Smith 1989:213). In the US, by contrast, it was found that, with the exception of English and Irish males, the tuberculosis death rate of cotton mill operatives was higher than among non-operatives, especially for women. This was attributed to the stress of the double burden which married women workers had to bear (Teller 1988:105).

If we look at the working environment of Japanese factories in the pre-Pacific War years, we find that they were generally overcrowded and ill-ventilated, especially up to World War I. Silk reeling mills were constantly full of steam from coccoon boilers, while humidity levels in cotton spinning factories were intentionally kept at a high level. Temperatures tended to rise to very high levels, reaching $35^{\circ} \mathrm{C}$ or even higher in summer. In winter cotton workers moved quickly between temperatures little above frecing and the $22^{\circ} \mathrm{C}$ of the mill (Koinuma 1925:22) Poor ventilation 
kept the level of carbon dioxide in the air very high,and the stench of oil combined with the build-up of carbon dioxide both caused lung damage and led to shallow breathing. In young people in particular this caused ill-developed and vulnerable lungs (Rōdō Jihō 1925:5). High levels of dust in the air in parts of the cotton spinning process promoted a variety of lung infections. By injuring lungs, dust and fumes assisted the invasion of the tuberculosis bacillus. The June, 1929, Safety Regulations for Factories included stipulations for the control of dust (ILO 1933:257). The relationship between dust and tuberculosis was the subject of debate, which focussed on the size of cotton dust grains, but by the 1920s research seemed to confirm that most days were lost to illness in the most dusty preparation and pre-spinning departments (mixing, ginning, carding etc.), results which researchers claimed were borne out by investigations in Germany as well (Koinuma 1925:23; Rōdō Jihō 1925:2). Even where doctors denied any connection between dust and tuberculosis, they were forced to acknowledge some connection between dust and respiratory problems (Itō 1948:11-12). Given that tuberculosis infection was passed on in water droplets, that dust in the air often forced workers to spit, and the bacillus was favoured by high (human body) temperatures, these conditions are significant. Fumes, poor ventilation and heat reduced vitality. With girls forced to wear damp working clothes outside the mill as work clothing was rarely provided, and subject to sudden temperature changes, resistance was clearly further lowered. 


\section{Length of Working Hours and Exhausrim!}

Western research again shows an occupational pattern here, with the disease disproportionately prevalent among workers with irregular hours and long shifts. Fatigue and overwork, often consequent on piecework rates, were deemed to make individuals lose strength, thereby making them more vulnerable to tuberculosis, but this was difficult to prove. Contemporary research in Japan confirmed this view. For example, a survey of bus conductresses carried out in the late 1930s indicated that their exhaustion over lengthy periods was of significance in the contraction of tuberculosis (Ōtsuka 1938:77). In all branches of textiles, working hours were very long and exhaustion common. One 1902 survey spoke of an eighteen-hour day in Suwa during the peak silk sat. . Kubota 1902:6), and another in 1901 found 12-13 year olds sleeping perhaps three-four hours out of twenty-four, ending up so tired that they could not eat (Yamane 1901:15). In the early cotton mills days off might be as little as three per year at this time (New Year, Obon and a local festival). By 1938 the number had risen to about two per month (Ōtsuka 1938: 79), but this still left frequent seven-day working weeks. Seasonal operation in silk meant a long winter break, but over time the industry moved towards year-round operation. The extensive use of night shifts in cotton spinning up to 1929 resulted in shortage of sleep and progressive weight loss (Ishihara 1913b:126), which was especially critical when most workers were immature young rirls. 


\section{Overcrowded Living Areas}

Poor housing was well established as an agent of tubercular infection from the turn of the century (Teller 1988:100; Hart \& Wright 1939:34). In overcrowded housing, infection was more easily communicated from one individual to another. It was proved that prolonged contact was the most common origin of clinical tuberculosis. Work on Glasgow (McFarlane 1989) has indicated the importance of tenement living in contributing to a continuing high rate of tuberculosis in the city when rates were falling elsewhere. In the Japanese textile industry, the majority of workers resided in company dormitories. Many were of a substantial size. The Nagano Factory Department in 1928 reported that there were 257 dormitories in the prefecture with over 100 residents (Kō 1928:2). Some of the larger mills sought to improve dormitory conditions, and firms such as Kanebō were well known for their efforts to monitor workers' health (Tōyōbō, 1929: 24), but these were in the minority, and the reputation of most mill residential facilities remained poor. Most dormitories were very crowded. One 1926 survey of 534 silk textile mills reported a single dormitory room for 708 occupants (Sasamura 1926:617). Many workers enjoyed space of less than 1 jō (about 6' by 3'), especially in Nagano, and for warmth in winter shared bedding with one other girl (Ishihara 1913b:129-30). Rapid turnover of workers meant that the same bedding could be used by 6-7 girls a year. One report in 1926 stated that in half the mills surveyed bedding was shared between two or even three girls, and similar complaints were still being made as late as 1938 
(Sasamura 1926:623; Ōtsuka 1938:79). The use of continuous double shifts in spinning meant not just that bedding could be in constant use by four girls every twenty-four hours, but that even during the day doors, windows and curtains were never opened, so bedding was never exposed to light or fresh air. Since bacilli contained in sputum and particles exhaled by infected individuals were more likely to be killed by light and exposure, or dispersed by good ventilation, such conditions encouraged the persistence of infectious dust and particles. In Nagano in the late 1920s it was still felt necessary to issue injunctions that bedding should be regularly changed and aired outside at least once every three months (Kō 1928:6). Even where management wished, this was not always easy without considerable capital expenditure. Buildings tended to be very dark. Four factories surveyed in 1926 had dormitories without any windows whatsoever (Sasamura 1926:10). Washing and cleaning conditions were often inadequate, and disinfectant frequently unavailable. Some reporters regarded the washing of utensils by each girl after communal meals as inviting the spread of infection (Kose 1926:201ff; Ōhashi 1911:24). ${ }^{9}$ There seems no doubt, therefore, that lack of ventilation, light and heating exacerbated conditions of dirt and overcrowding already identified by Ishihara as fostering infection (Ishihara 1913b:130-1).

9The view was that because of the hurry in which they ate, washing was totally inadequate, and would be better handed over to specialised staff. At the very least, the use of disinfectant was required. 


\section{Nutrition}

Of all the factors involved - housing, fatigue, anxiety, uncleanliness - poor nutrition with the impaired resistance that accompanied it, seems to have been the crucial divider between exposure and active manifestation of the disease.

(Smith 1989:19)

This view was borne out by the fact that at times of inadequate food supply the incidence of tuberculosis increased. In Europe during World War I, for example, tuberculosis mortality rates rose, particularly in Germany, where nutrition standards were especially bad. However, the nutrition factor was very difficult to measure. It did gradually become apparent, however, that a low protein intake could weaken an individual's resistance and immunity. In the West there was also a clear link with bovine tuberculosis, through the widespread consumption of beef and milk (Smith 1989:172-180). This latter feature was of far less relevance to Japan, despite the growth in meat consumption from the Meiji period, but a low quality of nutrition was a significant issue.

Diet varied tremendously from mill to mill. An early survey in 1901 spoke of a scant weekly diet consisting of basic foodgrains, pickles, hijiki (a kind of seaweed), bean curd (tofu) with leeks (negi), dried sardines, daikon (white radish) and beans. It was a diet with very little protein, especially animal protein, as there was no meat (Yamane 1901:15). However, another a year later spoke of fish or meat 2-4 times 
weekly (Kubota 1902:7). Ishihara in his survey reported that the food was quite good, and much improved over the previous ten years, as factories were improving diets to help overcome problems of recruitment (Ishihara 1913b:129). Some workers compared the diet they found favourably with what they might otherwise have consumed at home (Yamamoto 1972:337). Many workers did not, however, receive this kind of diet, getting little more than pickled daikon, watery miso soup and basic foodgrains. Diets in general were short of protein and fresh food, which was particularly important in the context of teenagers who were still growing. Even in relatively good mills nutrition was frequently inadequate for the harsh labour demands made on workers. The high rates of beriberi shown in the more comprehensive health surveys mentioned earlier point clearly to nutritional deficiency.

Whether in the case of Japan nutrition was as critical as Western writers have suggested is debateable. The high incidence of diseases such as beriberi were clearly related to diet (increasing through the shift to polished or half polished rice), but Japanese researchers concluded that it was difficult to extend the connection directly to tuberculosis (Koinuma 1925:21). It may well be, though, that as one scholar has suggested, we should be looking not at the quantity, but at the quality of nutrition, and analysing the effects of the high dependence on rice grain, and the low intake of both animal and other proteins (Saitō 1990:350). Whatever the case, it is likely 
that poor nutritional standards among many textile workers helped to undermine resistance.

\section{Low Wages and Poverty}

In the West tuberculosis was clearly not restricted to the poor, but its incidence among the poor was higher than among the better off. ${ }^{10}$ Most of the occupational groups among which tuberculosis was particularly prevalent consisted of low waged workers. Such workers were in addition more likely to experience one or more of the above environmental factors, identified as conducive to the spread of infection. They were also less likely to be able to pay for medical care which might help to combat the disease in its early stages. Textile workers were in general poorly paid, not least because they were women. ${ }^{11}$ With competitive piece rates normally operating, some workers were bound to be especially badly off. A system of forced savings was implemented by many companies, and constant pressure to remit substantial parts of their earnings to their homes, and to repay advances made, meant that most workers had relatively little left over to supplement their meagre diet by

${ }^{10}$ This fact was not taken seriously in Europe until after 1900 (Smith 1989:168), but was widely acknowledged by the interwar years.

${ }^{11}$ Long term trends in wage rates can be found in Umemura 1966 and Ohkawa 1967. Wage rates varied according to the branch of the industry, length of service etc., and were not necessarily poor in relation to what the same worker might have earned had she stayed in the agricultural sector. In general women textile workers earned around $50 \%$ of their male counterparts, and earned far below the average male wage. 
purchases from the factory shop or to pursue other courses of action which might have enhanced their resistance. Substantial improvements did occur in the 1920s1930s, but it was not easy to break out of the vicious cycle of long hours, low wages and poor conditions. It is very hard to draw a direct connection between the low wages earned by textile workers and the high rates of tuberculosis and other illnesses. Where financial poverty is particularly relevant is in the spread of infection, and the ability to pay for medical care. Sanpei Kōko, writing of as late as $19+\ldots$ uted that the particular poverty of weavers' families led to low nutritional standards and susceptibility to tuberculosis. She recounted how weavers from Ashikaga contracting tuberculosis were returned to their families in neighbouring hamlets, where they were compelled to sleep on straw, unable to afford a futon. They were ineligible for free medical care since they lacked the necessary futon and clothing to be admitted (Sanpei 1961:542-3). In Nagano it was reported that some doctors gave a $20 \%$ discount on prices to sick workers, but this could still mean payments of 30-40 sen per day, the equivalent of half to two-thirds the average daily wage in the area (Kose 1926:213). For the unwaged, such payments were clearly quite out of the question. Low wages and poverty may not have been the cause of tuberculosis, but it was closely correlated with the factors significant in its contraction, and the failure to treat it adequately. 


\section{Conclusion}

The conditions found in late nineteenth and early twentieth century Japanese textile mills were highly detrimental to the physical wellbeing of those who worked in them. Sickness rates, death rates, body weights and heights and other assessments of physical health all indicate that this was the case. Tuberculosis was only the most lethal and most conspicuous of their ailments, and as such caused unusual concern in a society long accustomed to relatively high mortality and morbidity rates. At a time when many of the formerly 'fatal' illnesses were on the wane, this particular one, closely identified with the industrialization process, seemed to be out of control. Yet high rates of illness and tuberculosis were far from being the monopoly of female textile workers. We have seen that other occupational groups, such as rubber workers, bus conductresses and weavers also experienced a high incidence of tuberculosis. Many other population groups experienced the environmental factors identified above. One 1940 survey found cotton mill workers complaining that work at home in the countryside was far harder, because they were no longer used to it (Sangyō Fukuri 1940: 66). Reports on village homes in the 1940s spoke of them as overwhelmingly dark, dirty and ill-ventilated. ${ }^{12}$ General nutrition was poor, with beriberi a nationwide affliction for most of the prewar and

${ }^{12} \mathrm{I}$ am grateful to Professor M.Satō of the Institute for the Documentation of Japanese Economic Statistics, Hitotsubashi University, for drawing my attention to this information. 
early postwar periods. Many other workers enjoyed minimal incomes. The same conditions which researchers highlighted could be found in varying degrees in the life and work of many Japanese. If the conditions female textile workers lived and worked in were conducive to the spread of tubercular infection, then so were the same conditions in both city and countryside, where exhaustion, overcrowding, dirt and poverty were also prevalent. Ninety per cent of the silk workers interviewed by Yamamoto Shigemi said that they were glad to have gone to the mills, and that it was on balance preferable to staying at home (Yamamoto 1972:337).

Why, then, did the issue of tuberculosis among female mill workers assume such a particular prominence in a society not normally noted for its altruistic and humanitarian concern with its female labour force? Several reasons may be suggested. The first relates to the whole industrialization process itself. Japan was a late industrializer, and policymakers felt themselves under immense pressure to industrialize the country with great rapidity. This resulted in economic and business strategies which were recognised to have considerable costs in human terms. They nevertheless came to realise that for a variety of reasons -for example foregone profits, labour discontent, low labour productivity, an unhealthy female population leading to unhealthy children - high sickness and mortality rates among industrial workers were not conducive to enhanced national efficiency. The key role of the textile industries in the prewar industrialization process highlighted this concern. Ishihara and his colleagues were effectively $\mathrm{sa}_{y} \pm \mathrm{i}$ g that the ill-health and mortality 
of these workers was the price of national progress, but that this cost could not over the long term be justified in either economic or humanitarian terms. The campaign for factory legislation, spearheaded by members of the bureaucracy, argued along the same lines.

Factory managements, however, also claiming to operate within limits imposed by Japan's position as a late industrializer, were unable or unwilling to eradicate the conditions which appeared to encourage the spread of tuberculosis and other diseases. They blamed capital shortages and the pressure to 'catch-up' for the nonavailability of funds to improve working and living conditions. They could persuade themselves, and others, that young country girls on temporary contracts could endure the undoubted hardships of mill life (Tsurumi 1990:172). In cotton, where tuberculosis was most rampant, turnover was already high, workers relatively quickly trained, and managers assumed (sometimes erroneously) that there was an ample supply of labour. With one or two exceptions, it was only after World War I that some companies even started to recognise the value of investment in improved labour conditions to reduce recruitment costs and raise productivity. Better approaches to tuberculosis in large mills were just one aspect of this strategy. The worker health issue was thus for managers a sensitive issue whose implications they were compelled to acknowledge, but which, they claimed, was thoughtlessly brandished by strident critics ignorant of the economic realities under which companies had to operate. 
Perhaps the most powerful reason for the prominence of the tuberculosis issue in contemporary thinking, however, is its importance for the rural community. As stated at the beginning, most female textile workers were migrants, whose patterns of life and work can only be understood in the context of their agrarian background. Contemporary Japanese researchers and policy makers, faced by a population still largely agrarian, identified in this rural link consequences for the economy and society which they saw as far more tragic than the deaths and illness of the workers themselves. This was the rapid spread of tuberculosis through the rural areas, which, it was argued, would threaten population growth, increase poverty, harm agricultural production and undermine the very foundations of Japanese society. Figures do give support to a relative increase in contraction in the countryside. While tuberculosis remained more of an urban phenomenon, partly due to the concentration of young people (the worst affected age groups) in the cities, there was evidence that the disparity between urban and rural tuberculosis mortality rates was less than previously thought, and of increasing rates in the countryside (Yoshioka 1941:259). Female textile workers were viewed as a major agent for the damaging spread of tuberculosis in rural areas.

The evidence for this claim was largely anecdotal. It proved easy to find stories of families and villages which had lost half or more of their members to tuberculosis after a girl had returned from a mill suffering from the disease (eg. Tōyōbō 1929:19ff.). It proved more difficult to provide statistical evidence of such a link. 
The area where the disease was acquired was not necessarily that where death occurred. Mills invariably discharged workers in the early stages of tuberculosis. Often they did go back to their home village to recover, or, in many cases, to die, but sometimes they stayed in the cities, trying to keep on earning a living. As a result, tuberculosis was not necessarily focussed on areas with a high incidence of textile mills. Moreover, sick workers were rarely listed according to area of origin. ${ }^{13}$ Very few surveys looked at the post-work health of textile workers, and while peasant household surveys proliferated in the interwar years, they provided relatively little documentary evidence on this particular relationship. Nevertheless, regional concentrations of tuberculosis infection existed, and national statistics showed that concentrations of deaths from tuberculosis came in areas of previous high outmigration (Taeuber 1956:308). Research correlated high tuberculosis death rates not just with industrialization, the degree of population concentration and the level of income, but also with the rate of dekasegi occurring in a region (Yoshioka 1941:267). While dekasegi might be a high risk occupation, belonging to a dekasegi family appeared to be equally dangerous to one's health. Moreover, for much of this time migrant labour played a crucial part not only in the growing industrial sector, but in sustaining the rural sector itself.

${ }^{13}$ Sick workers rarely seem to be categorized by both nature of illness and place of origin. One exception is Ötsuka 1938, which lists factory workers suffering from syphilis according to regional origin. 
The continuing high rates of tuberculosis despite rising national income distinguishes Japan from other countries industrializing in the pre-World War II years. The industrialization process in Japan, as elsewhere, clearly produced substantial changes in the living and disease environment. This affected not just female textile workers, but the population as a whole. Although living and working environments may have improved in certain respects, in other facets of life there was a deterioration, or at least a change, which proved to be of particular relevance to the spread of tubercular infection. That the issue of tuberculosis gained such prominence was due not just to the high rates, but to their implications for national efficiency, economic management and rural life.

The health and tuberculosis debate thus had a significance which went far beyond medical and humanitarian considerations. As such, it has provided powerful evidence for a whole school of historiography. Medical research helped to reinforce the enduring perception of female textile workers as the archetypal exploited workforce found in so many texts on labour history (eg. Nakamura 1976; Ōkōchi 1965; Tsurumi 1990). The tuberculosis issue helped to reinforce the view of many Japanese historians that textile workers were the victims of inhuman exploitation, whose experience was powerful evidence of the iniquities of the emergent capitalist system. 


\section{$\underline{\text { References }}$}

Dore, R.P. (1969) 'The modernizer as special case: Japanese factory legislation, 1882-1922' Comparative Studies in Society and History 11, 4

Fogel, R.W. (1986) 'Nutrition and the decline in mortality since 1700: some preliminary findings' in S.L.Engerman \& R.E.Gallman (eds.) Long Term Factors in American Economic Growth (Chicago: Chicago University Press)

General Headquarters Supreme Commander for the Allied Powers, Public Health and Welfare Section (GHQ SCAP) (n.d.) Public Health and Welfare in Japan, vol.1 (Tokyo: SCAP)

Hart, P.D'Arcy, and Wright, G.Payling (1939) Tuberculosis and Social Conditions in England, with Special Reference to Young Adults (London: National Association for the Prevention of Tuberculosis)

Hosoi, Wakizō (1925) Jōkō Aishi (repr. 1976 Tokyo: Iwanami Shoten)

International Labour Office (ILO) (1933), Industrial Labour in Japan (Geneva: International Labour Office)

Ishihara, Osamu (1913a) 'Jokō no eiseigakuteki kansatsu'

Ishihara, Osamu (1913b), 'Jokō to kekkaku'

both in Kokka Igakkai Zasshi 322, November

Itō, Minoru (1948) 'Boseki to kekkaku’ Nihon Bōseki Geppō 12, February

Jannetta, Ann B.(1986) Epidemics and Mortality in Early Modern Japan (Princeton: Princeton University Press) 
Kagoyama, Takashi (1970), 'Introduction' to Ishihara Osamu, Jokō to Kekkaku, no.5 of Seikatsu Koten Sōsho (Tokyo: Koseikan)

Kō, Isaburō (1928) 'Jokō kishukusha no shakan ni tsuite' Sangyō Fukuri 3, 11, November

Kobayashi, Tango (1965) Kōjōhō to Rōdō Undō (Tokyo: Aoki Shoten)

Koinuma, Engo (1925) ‘Bōseki jokō no shippei’ Rōdō Jihō 2, 12, December

Kose, Yasutoshi (1926) ‘Jokō no kanbō oyobi ichōbyō ni kansuru kosatsu’ Shakai Seisaku Jihō 67, April

Kubota, Seitarō (1902) 'Kōjō eisei ni tsuite' Kokka Igakkai Zasshi 188, December McFarlane, Neil (1989) 'Hospitals, housing and tuberculosis in Glasgow', paper presented at the Economic History Society Conference, Exeter

Molony, Barbara (1991) 'Activism among women in the Taishō cotton textile industry' in G.Bernstein (ed.) Recreating Japanese Women, 1600-1945 (Berkeley: University of California Press)

Naimushō Shakaikyoku (1926) Kōgyō to Kekkaku (Tokyo: Sangyō Fukuri Kyōkai) Nakamura, Masanori (1976) Rōdōsha to Nōmin, vol.29 of Nihon no Rekishi (Tokyo: Shogakkan)

Nishikawa, Shunsaku \& Abe, Takeshi (1990) 'Gaisetsu - 1885-1914' in S.Nishi! awa \& T.Abe (eds.) Sangyōka no Jidai - Jō, vol.4 of Nihon Keizaishi (Tokyo: Iwanami Shoten)

Nōshōmushō Shōkōkyoku (1903) Shokkō j: (repr. 3 vols. 1976, with an introduction by Tsuchiya Iakao, Tokyo: Shinkigensha) 
Ōhashi, Mamoru (1911) ‘N,S bōseki kabushiki gaisha eisei jōkyō’ Kokka Igakkai Zasshi 289, May

Ohkawa, Kazushi et.al. (eds.) (1967) Bukka, vol.8 of Long Term Economic Statistics of Japan (Tōkyō: Toyo Keizai Shinpōsha)

Okazaki, Yoichi (1986) 'Meiji Taishō ki ni okeru Nihon jinkō no dōtai’ Jinkō Mondai Kenkyū 178

Ōkōchi, Kazuo, \& Matsuo, Hiroshi (1965) Nihon Rōdō Kumiai Monogatari, 3 vols.(Tokyo: Chikuma Shobo)

Ōtsuka, Kanō (1938) 'Fujin rōdō mondai hōkoku' Rōdō Kagaku Kenkyū 15, 1, January

Powell, Margaret, \& Anesaki, Masahira (1990) Health Care in Japan (London: Routledge)

Rōdō Jihō (1924) 'Seishi shokko no kenko shindan seiseki’ Rōdō Jihō 1, 10, October

Rōdō Jihō (1925) ‘Menshi Bōseki Kōjō no Eisei’ Rōdō Jihō 2, 6, June Saitō, Osamu (1989) 'Keizai hattatsu wa mortality teika o motarashita ka? - Ōbei to Nihon ni okeru eiyō - taii - heikin yōmei' Keizai Kenkyū 40, 4, October Sangyō Fukuri (1940) 'Kurihara bōshoku gōmei kaisha ni okeru joshi kōin seikatsu zadankai' Sangyō Fukuri 15, 10, October

Sanpei, Kōko (1961) Nihon Kigyō Shi (Tokyo: Yũzankaku)

Sasamura, Etsuo (1926) 'Sen'i kōjō fuzoku kishukusha no eiseiteki kansatsu’ Shakai Igaku Zasshi 477, October 
Smith, F.B. (1988) The Retreat of Tuberculosis (London: Croom Helm)

Taeuber, Irene B. (1958) The Population of Japan (Princeton: Princeton University Press)

Taira, K. (1970) 'Factory legislation and management modernization during Japan's industrialization 1886-1916' Business History Review 44, 1

Tanino, Setsu (1937) 'Bōseki jokō taishokugo no kisū ni kansuru chosa' Sangyō Fukuri 12, 11, November

Teller, Michael E. (1988) The Tuberculosis Movement: a Public Health Campaign in the Progressive Era (New York, Westport \& London: Greenwood Press) Tōyō Bōseki Kabushiki Gaisha Eiseika (1929) Tōyō Bōseki Jokō Igakuteki Kenkyū (Tōyō Bōseki, September)

Tsurumi, E.Patricia (1990) Factory Girls: Women in the Thread Mills of Meiji Japan (Princeton: Princeton University Press)

Umemura, Mataji et.al. (ed.) (1966) Nōringyō, vol.9 of Long Term Economic Statistics of Japan (Tokyo: Tōyō Keizai Shinpōsha)

Umemura, Mataji (ed.) (1988) Rōdōryoku, vol.2 of Long Term Economic Statistics of Japan (Tokyo: Tōyō Keizai Shinpōsha)

Wrigley, E.A. \& Schofield, R.S. (1981) The Population History of England 15411971 (London: E.A.Arnold)

Yamamoto, Shigemi (1972) Aa Nomugi Tōge (Tokyo: Asahi Shinbunsha)

Yamane, Seiji (1901) 'Kōgyō eisei shisatsu dan’ Kokka Igaku Zasshi 175, November 
Yokoyama, Gennosuke (1898) Nihon no Kasō Shakai (repr. 1976 Tokyo: Iwanami Shoten)

Yoshioka, Hirohito (1941) ‘Honpō haikekkaku no ekigakuteki tokuchō’ Nihon Rinshō Kekkaku 2, 2 


